\title{
Interface Resistance between FeCr Interconnects and La0.85Sr0.15MnO3
}

\section{Mikkelsen, Lars; Hendriksen, Peter Vang}

Published in:

Meeting Abstracts - Electrochemical Society

Publication date:

2009

Document Version

Publisher's PDF, also known as Version of record

Link back to DTU Orbit

Citation (APA):

Mikkelsen, L., \& Hendriksen, P. V. (2009). Interface Resistance between FeCr Interconnects and

La0.85Sr0.15MnO3. In Meeting Abstracts - Electrochemical Society (pp. Abstract 1598). The Electrochemical Society.

\section{General rights}

Copyright and moral rights for the publications made accessible in the public portal are retained by the authors and/or other copyright owners and it is a condition of accessing publications that users recognise and abide by the legal requirements associated with these rights.

- Users may download and print one copy of any publication from the public portal for the purpose of private study or research.

- You may not further distribute the material or use it for any profit-making activity or commercial gain

- You may freely distribute the URL identifying the publication in the public portal

If you believe that this document breaches copyright please contact us providing details, and we will remove access to the work immediately and investigate your claim. 
Interface resistance between $\mathrm{FeCr}$ Interconnects and $\mathrm{La}_{0.85} \mathrm{Sr}_{0.15} \mathrm{MnO}_{3}$

L. Mikkelsen and P.V. Hendriksen

Fuel Cells and Solid State Chemistry Division Risø National Laboratory for Sustainable Energy The Technical University of Denmark

Frederiksborgvej 399, DK-4000 Roskilde, Denmark

The long term oxidation behaviour and the electrical interface resistance between $\mathrm{FeCr}$ alloy sheets and $\mathrm{La}_{0.85} \mathrm{Sr}_{0.15} \mathrm{MnO}_{3}$ plates was studied by a DC four-point method in air at $750^{\circ} \mathrm{C}$ for $10000 \mathrm{~h}$. The test was terminated with thermal cycles. The tested $\mathrm{FeCr}$ alloys were: Crofer 22 APU, Sanergy HT and Plansee alloys. The alloys were slurry sprayed with a dual layer coating consisting of an inner cobalt containing oxide and an outer perovskite containing oxide layer. The microstructure and composition of the oxide scales formed at the interfaces was investigated using SEM/EDX analysis.

Low degradation rates of less than 1 $\mathrm{m} \Omega \mathrm{cm}^{2} / 1000 \mathrm{~h}$ were measured on several of the interfaces. The microstructure analysis showed that a duplex $\mathrm{Cr}_{2} \mathrm{O}_{3}$-spinel oxide scale with a thickness of 4-5 $\mu \mathrm{m}$ was grown on the alloys. The relative thickness of the $\mathrm{Cr}_{2} \mathrm{O}_{3}$ and spinel layers varied between the alloys showing that minor compositional changes of the alloys affect the oxide formation. Furthermore, the composition of the spinel was affected by the composition of the alloy as well as the composition of the dual layer coating.

The low degradation rates measured during the $10000 \mathrm{~h}$ long term test is promising for the lifetime durability of slurry coated interconnects in SOFC stacks. 